\title{
Chemospecific and diastereoselective synthesis of bis-dioxabicyclo[2.2.1]heptanone ring systems
}

\section{Sengodagounder Muthusamy,* Janagiraman Krishnamurthi, and Eringathodi Suresh}

Central Salt and Marine Chemicals Research Institute, Bhavnagar - 364 002, India

E-mail: muthu@,csmcri.org

\section{This paper is dedicated to Prof. S. Swaminathan in recognition of his outstanding contributions to organic chemistry}

(received 17 Nov 04; accepted 29 Dec 04; published on the web 07 Jan 05)

\begin{abstract}
Chemospecific and diastereoselective methods for the construction of bisdioxabicyclo[2.2.1] heptanone ring systems using $\mathrm{Rh}_{2}(\mathrm{OAc})_{4}$-catalyzed tandem reactions of $\alpha$ diazo ketones with keto-functional groups as dipolarophiles are described. Diketone functionalities were utilized to undergo highly efficient tandem cyclization-cycloaddition to furnish the bis-dioxabicyclo[2.2.1] heptanone spirocycles. This process served both as a simple and superior method for multi bond formation in a single synthetic operation.
\end{abstract}

Keywords: Carbonyl ylides, 1,3-dipolar cycloaddition, diazo ketones, rhodium(II) acetate, dioxabicyclo[2.2.1] heptanone ring systems

\section{Introduction}

Achieving the maximum pertinent complexity increase while minimizing the number of steps is an ideal in synthetic organic chemistry. ${ }^{1}$ Reactions leading to multi C-C bond formations through tandem processes, which can rapidly generate the molecular complexity in a controlled and predictable manner, is a contemporary theme in modern organic synthesis and finds application in accessing newer entities. Tandem processes of diverse nature, promoted through catalysis, thermal or photochemical activation have already proven their utility in organic synthesis and found many applications in the acquisition of complexity in the form of functionalized carboand heterocyclic systems. Reactions based on carbenoid transformations are among the synthetically most useful to increase the molecular complexity. ${ }^{2,3}$ Rhodium(II) carbenoid generated from $\alpha$-diazo carbonyl compounds and their subsequent reactions play an important role in synthetic organic chemistry to design various polycyclic compounds with regio- and stereocontrol. This methodology serves as an important protocol to construct bonds for the 
synthesis of complex molecules ${ }^{3}$ and various natural products ${ }^{4}$ with atom economy. Thus, this methodology generates considerable interest and intensive investigation in synthetic organic chemistry. Metallo-carbenoid cyclization with a carbonyl group represents a most important method for the generation of carbonyl ylides from $\alpha$-diazo carbonyl compounds and their subsequent 1,3-dipolar cycloaddition reactions with $\mathrm{C}=\mathrm{C}$ bonds have been well documented. ${ }^{3}$ From a survey of the literature, only a few examples are known for the 1,3-dipolar cycloaddition of carbonyl ylides with heterodipolarophiles such as carbonyl group. For example, reactions of five- or six-membered-ring cyclic carbonyl ylides with $o$-quinones, ${ }^{5} p$-benzoquinones, ${ }^{6,7} 1,2$ diketones $^{8}$ and other carbonyl compounds ${ }^{9}$ have been studied to afford 1:1, 2:1 or 3:1 cycloadducts without any selectivity in the presence of copper or rhodium catalysts. These tandem cyclization-cycloaddition protocols have been successfully utilized in the synthesis of important biologically active compounds such as brevicomins ${ }^{10}$ and zaragozic acid $\mathrm{A}^{11}$ using propionaldehyde and glyoxalate as heterodipolarophiles, respectively. Furthermore, the dioxabicyclo[2.2.1] heptanone skeleton is present in a wide range of natural products and exists as part of polycyclic frameworks e.g. loukacinols, ${ }^{12}$ xanthane epoxide, ${ }^{13}$ and isogosterones. ${ }^{14}$ But the chemistry and the selectivity of these reactions have not been investigated well. The control of the stereoselectivity in the cycloaddition reactions of carbonyl ylides poses a challenge with the prospect of applications towards the synthesis of natural products. In continuation of our interest in the synthesis of highly substituted epoxy-bridged poly- or spirocyclic frameworks, ${ }^{6,8,15}$ we recently reported on the chemoselective synthesis of multiple dioxabicyclo[2.2.1]heptanone ring systems. ${ }^{16}$ We herein report the detailed investigation on the tandem cyclization-[3+2]cycloaddition reactions of five-membered-ring carbonyl ylides for the synthesis of bisdioxabicyclo[2.2.1] heptanone ring systems.

\section{Results and Discussion}

It was envisaged that the reaction of $\alpha$-diazo ketones such as $\mathbf{1}$ or $\mathbf{4}$ with $\mathrm{Rh}_{2}(\mathrm{OAc})_{4}$ could generate the corresponding rhodium carbenoids 2 or $\mathbf{5}$ based on our earlier work. ${ }^{6}$ The respective transient five-membered-ring cyclic carbonyl ylides $\mathbf{3}$ or $\mathbf{6}$ could successfully be generated by nucleophilic attack of ring oxygen atom to electron deficient rhodium-carbenoid carbon atom present in intermediates $\mathbf{2}$ or $\mathbf{5}$ (Scheme 1).

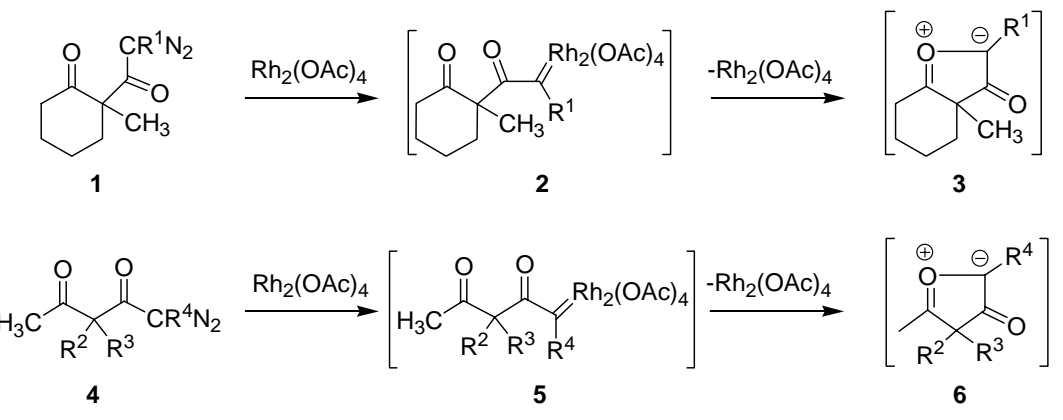

\section{Scheme 1}


Thus, the required starting materials of type $\mathbf{1}$ or $\mathbf{4}$ were prepared according to the literature procedure $^{6}$ and the tandem cyclization-cycloaddition reactions of the diazo ketones $\mathbf{1}$ or $\mathbf{4}$ with the keto-functional groups as heterodipolarophile have been investigated (Table 1).

Table 1. Generation of five-membered-ring cyclic carbonyl ylides $\mathbf{3}$ or $\mathbf{6}$ from $\alpha$-diazo ketones $\mathbf{1}$ or 4

\begin{tabular}{llllll}
\hline Entry & $\begin{array}{l}\alpha \text {-diazo } \\
\text { ketone }\end{array}$ & $\mathrm{R}^{1}$ & $\mathrm{R}^{2}$ & $\mathrm{R}^{3}$ & $\mathrm{R}^{4}$ \\
\hline 1 & $\mathbf{1 a}$ or 3a & $\mathrm{H}$ & - & - & - \\
2 & $\mathbf{1 b}$ or 3b & COOEt & - & - & - \\
3 & $\mathbf{4 a}$ or $\mathbf{6 a}$ & - & $\mathrm{CH}_{3}$ & $\mathrm{CH}_{3}$ & $\mathrm{H}$ \\
4 & $\mathbf{4 b}$ or $\mathbf{6 b}$ & - & $\mathrm{CH}_{3}$ & $\mathrm{CH}_{3}$ & COOEt \\
5 & $\mathbf{4 c}$ or $\mathbf{6 c}$ & - & $-\left(\mathrm{CH}_{2}\right)_{2-}$ & & $\mathrm{H}$ \\
\hline
\end{tabular}

Initially, we studied the reaction of cyclic diazo ketones 1 with the compound having two keto-groups placed in 1,4-fashion on a rigid cyclic system. For this purpose, an excess of cyclohexane fused diazo ketone 1a was added to a dichloromethane solution containing anthraquinone and a catalytic amount of $\mathrm{Rh}_{2}(\mathrm{OAc})_{4}$ under an argon atmosphere. The reaction afforded the symmetric bis-cycloadduct 7 in $60 \%$ yield (Scheme 2). The formation of bisdioxabicyclo[2.2.1] heptanone ring system 7 in a chemospecific and diastereoselective manner was confirmed by spectral and crystallographic analyses. Similarly, the reaction of diazo ketone 4a and cyclopropane fused acyclic diazo ketone $4 \mathbf{c}$ with anthraquinone afforded the respective symmetric bis-cycloadducts $\mathbf{8}$ and $\mathbf{9}^{16}$ in good yields (Scheme 2, Table 2) as a single isomer.
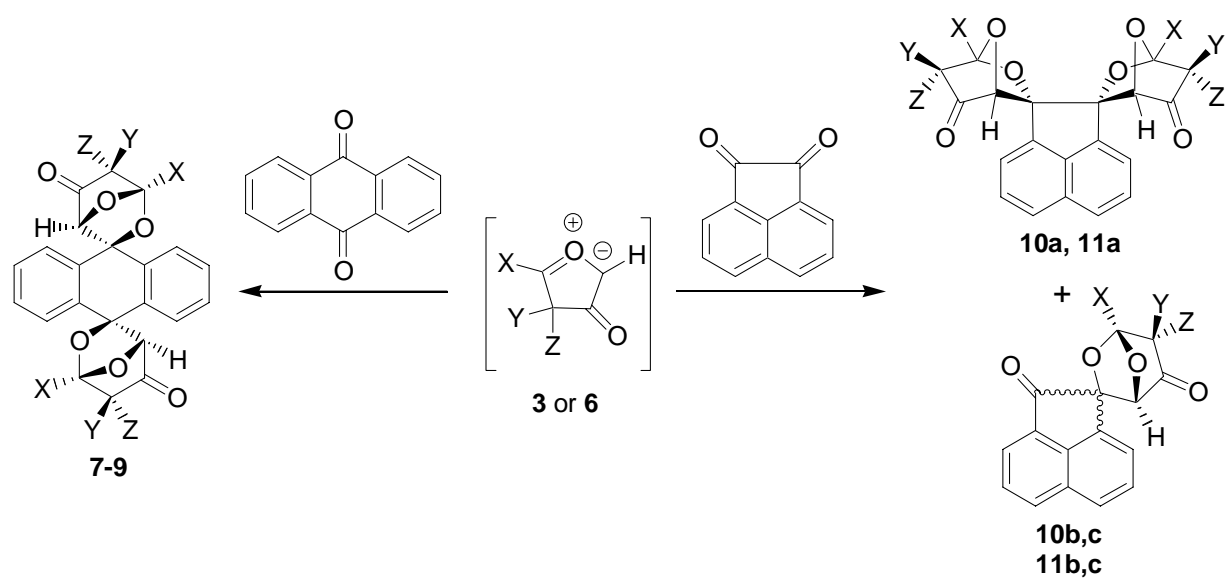

\section{Scheme 2}

Consequently, we chose acenaphthenequinone as another dipolarophile, where keto-groups are placed in 1,2-fashion to investigate the above reaction in the presence of excess diazo ketones 
$1 \mathbf{a}$ and 4a. Thus, we performed the reaction of excess $\alpha$-diazo ketone $\mathbf{1 a}$ with acenaphthenequinone in the presence of $\mathrm{Rh}_{2}(\mathrm{OAc})_{4}$ to furnish bis-dioxabicyclo[2.2.1] heptanone ring system 10a as a minor isomer along with mono-dioxabicyclo[2.2.1] heptanone ring systems 10b,c as a diastereomeric mixture. And the crude nmr spectrum showed the formation of products in the ratio of 1:1:1.5. Similarly, diazo ketone 4a with acenaphthenequinone afforded bis-epoxy-bridged cycloadduct 11a as a minor isomer along with mono-epoxy-bridged cycloadducts 11b,c as a diastereomeric mixture and the crude nmr spectrum showed the formation of products in the ratio of 1:1:1.5. The bis-cycloadducts 10a and 11a were obtained only in poor (20 and $25 \%$ ) yields even in the presence of excess diazo ketones. A reason for this may be due to steric hindrance arising from the proximity of an already installed dioxabicyclo[2.2.1]heptanone ring system.

Table 2. Reaction of carbonyl ylides $\mathbf{3}$ or $\mathbf{6}$ with anthraquinone and acenaphthenequinone

\begin{tabular}{llllll}
\hline Entry & $\mathrm{X}$ & $\mathrm{Y}$ & $\mathrm{Z}$ & Product & Yield (\%) \\
\hline 1 & $-\left(\mathrm{CH}_{2}\right)_{4^{-}}$ & & $\mathrm{CH}_{3}$ & $\mathbf{7}$ & 60 \\
2 & $\mathrm{CH}_{3}$ & $\mathrm{CH}_{3}$ & $\mathrm{CH}_{3}$ & $\mathbf{8}$ & 70 \\
3 & $\mathrm{CH}_{3}$ & $-\left(\mathrm{CH}_{2}\right)_{2-}$ & & $\mathbf{9}$ & $75^{\mathrm{b}}$ \\
4 & $-\left(\mathrm{CH}_{2}\right)_{4^{-}}$ & & $\mathrm{CH}_{3}$ & $\mathbf{1 0 a}$ & $20^{\mathrm{c}}$ \\
5 & $\mathrm{CH}_{3}$ & $\mathrm{CH}_{3}$ & $\mathrm{CH}_{3}$ & $\mathbf{1 1 a}$ & $25^{\mathrm{c}}$ \\
\hline
\end{tabular}

${ }^{a}$ Yields (unoptimized) refer to isolated and chromatographically pure compounds. ${ }^{\mathrm{b}}$ Ref.16. ${ }^{\mathrm{c}}$ Only the yield of bis-cycloadduct is provided.

After studying the tandem reaction of diazo ketones with 1,2- and 1,4-diketo functionalities placed on a rigid ring system, we extended the reaction of cyclic carbonyl ylides $\mathbf{3}$ and $\mathbf{6}$ with substrates having 1,4-diketo-functionalities on a flexible ring system. Thus, an excess of diazo ketone 1a was reacted with 1,4-cyclohexanedione in the presence of a catalytic amount of $\mathrm{Rh}_{2}(\mathrm{OAc})_{4}$ under an argon atmosphere. The crude reaction mixture was investigated by ${ }^{1} \mathrm{H}$ NMR spectroscopy, which indicated formation of the bis-dioxabicyclo[2.2.1] heptanone ring system as a mixture of diastereomers in the ratio of 1:3. These diastereomers were separated by column chromatography to afford products $\mathbf{1 3 a}$ and $\mathbf{1 3 b}$ in 45 and $17 \%$ yield, respectively (Scheme 3, Table 3). The IR spectrum of compound 13a showed a band at $1763 \mathrm{~cm}^{-1}$ for the presence of a keto-functionality in a strained ring. The ${ }^{1} \mathrm{H}$ NMR spectrum of compound 13a exhibited two singlets for both the bridgehead protons $\left(\mathrm{H}_{\mathrm{a}}\right)$ at 4.23 and $4.21 \mathrm{ppm}$. Characteristically, ${ }^{13} \mathrm{C}$ NMR spectrum of the product 13a showed a single resonance at 87.2, 214.1 ppm for the bridgehead $^{17}$ $\left(\mathrm{C}-\mathrm{H}_{\mathrm{a}}\right)$ and the carbonyl $(\mathrm{C}=\mathrm{O})$ carbons, respectively. Further, the single crystal X-ray crystallographic analysis ${ }^{18}$ of compound 13a (Figure 1) clearly revealed that the stereochemistry of the interesting bis-cycloadduct 13a has the trans-geometry on cyclohexane ring system. Based on the interrelated spectroscopic analyses, the minor isomer was tentatively assigned as biscycloadduct 13b with cis-geometry. 


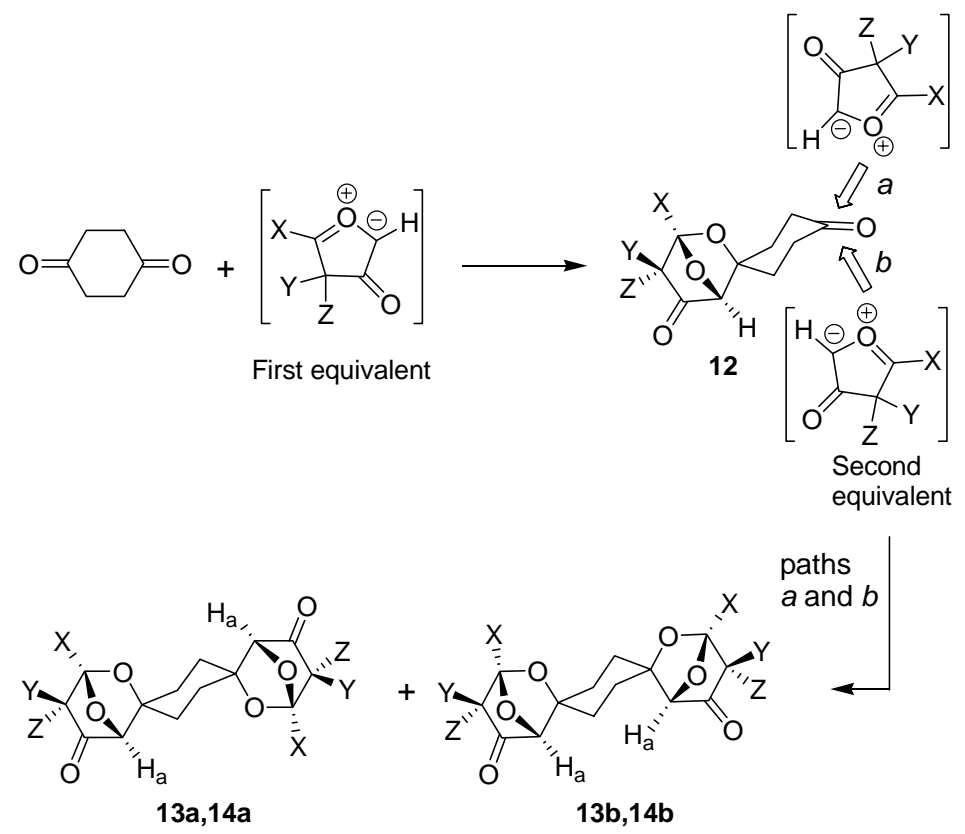

\section{Scheme 3}

Table 3. Reaction of carbonyl ylides 3a or 6a with 1,4-cyclohexanedione

\begin{tabular}{lllllll}
\hline Entry & $\mathrm{X}$ & $\mathrm{Y}$ & $\mathrm{Z}$ & Product & Yield $^{\mathrm{a}} \%$ & $\begin{array}{l}\text { Stereochemistry on } \\
\text { cyclohexane ring }\end{array}$ \\
\hline 1 & $-\left(\mathrm{CH}_{2}\right)_{4^{-}}$ & $\mathrm{CH}_{3}$ & $\mathbf{1 3 a}$ & 45 & trans \\
& & & & $\mathbf{1 3 b}$ & 17 & cis \\
2 & $\mathrm{CH}_{3}$ & $\mathrm{CH}_{3}$ & $\mathrm{CH}_{3}$ & $\mathbf{1 4 a}$ & 23 & trans \\
& & & & $\mathbf{1 4 b}$ & 45 & cis \\
\hline
\end{tabular}

${ }^{a}$ Yields (unoptimized) refer to isolated and chromatographically pure compounds.

It is apparent that two consecutive 1,3-dipolar cycloaddition reactions took place with carbonyl groups of 1,4-cyclohexanedione rather than at the carbonyl groups present on dioxabicyclo[2.2.1]heptane ring system of the initially formed dioxabicyclo[2.2.1] heptane ring system of the mono-cycloadduct 12 to eventually yield the bis-cycloadducts 13a,b in a chemospecific manner. After the first cycloaddition, the keto-group present on the cyclohexane ring of product 12 (obtained via mono-cycloaddition of carbonyl ylide 3a) constitutes a platform, which led to two possible reaction pathways as shown in Scheme 3. Route a shows that the reaction of the carbonyl ylide dipole via equatorial addition to the keto-group of compound 12 leads to the trans isomer 13a. The alternative pathway, route $b$, indicates reaction of the carbonyl ylide dipole via axial addition to the keto-group of compound $\mathbf{1 2}$ to furnish the cis-isomer $\mathbf{1 3 b}$. 


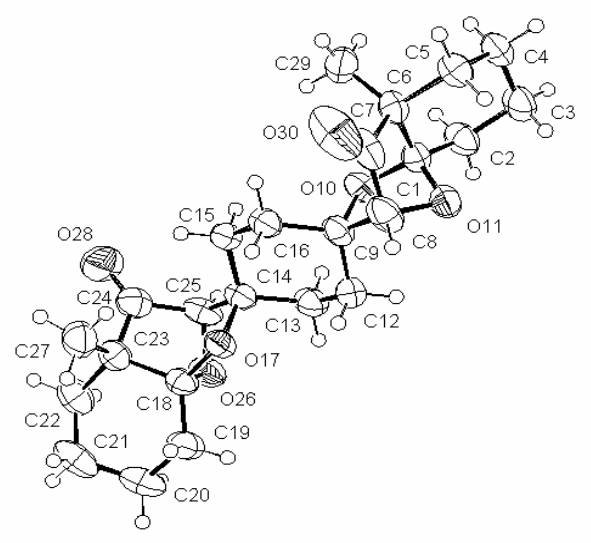

Figure 1. ORTEP diagram of compound 13a.

A similar reaction was performed with diazo ketone 4a to afford products 14a,b in 23 and $45 \%$ yield, respectively. The spectroscopic analyses revealed that the products 14a,b were derived from the double cycloaddition of carbonyl ylides to the carbonyl groups of 1,4cyclohexanedione as a diastereomeric mixture in the ratio of 1:2. The stereochemistry of product 14b is unequivocally confirmed as the cis-geometry on cyclohexane ring system based on the single-crystal X-ray analysis ${ }^{19}$ (Figure 2). The stereochemistry of compound 14a is tentatively assigned as the trans-geometry based on the interrelated spectral analysis. Interestingly, we did not observe any other cycloadducts arising from the carbonyl groups present in the oxanorboranane ring system.

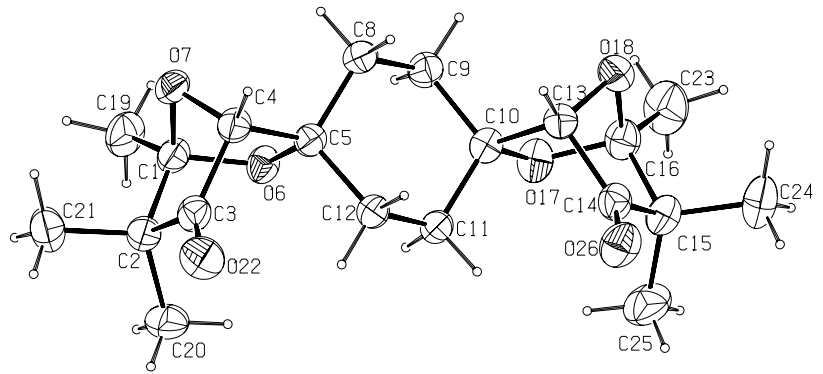

Figure 2. ORTEP diagram of compound $\mathbf{1 4 b .}$

The trans- and cis-isomers were predominant, when the diazo ketones 1a and 4a employed, respectively (Table 3). A reason for this may be due to the preference of approach of the respective carbonyl ylide intermediates 3a and 6a (path $a$ and $b$, Scheme 3). This interesting observation encouraged us to further investigate to achieve a single isomer. To this end, we planned to replace $\mathrm{H}_{\mathrm{a}}$ in products 13 and 14 by an ethyl ester group. Thus, reaction was 
conducted between 1,4-diketocyclohexane and diazo ketone 1b. Interestingly, this reaction afforded bis-cycloadduct 16a as a single isomer in good yield (Scheme 4, Table 4). Singlecrystal X-ray crystallographic analysis ${ }^{20}$ of bis-cycloadduct 16a confirmed its trans-geometry. Similarly, the reaction of diazo ketone $\mathbf{4} \mathbf{b}$ having ester functionality also furnished compound 17a as a single isomer and its stereochemistry is also assigned the trans-geometry based on the spectral similarities to $\mathbf{1 6 a}$.

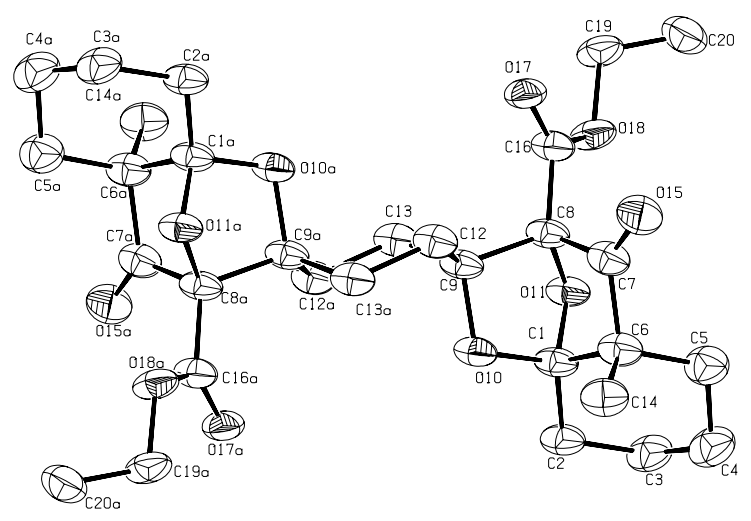

Figure 3. ORTEP diagram of compound 16a.

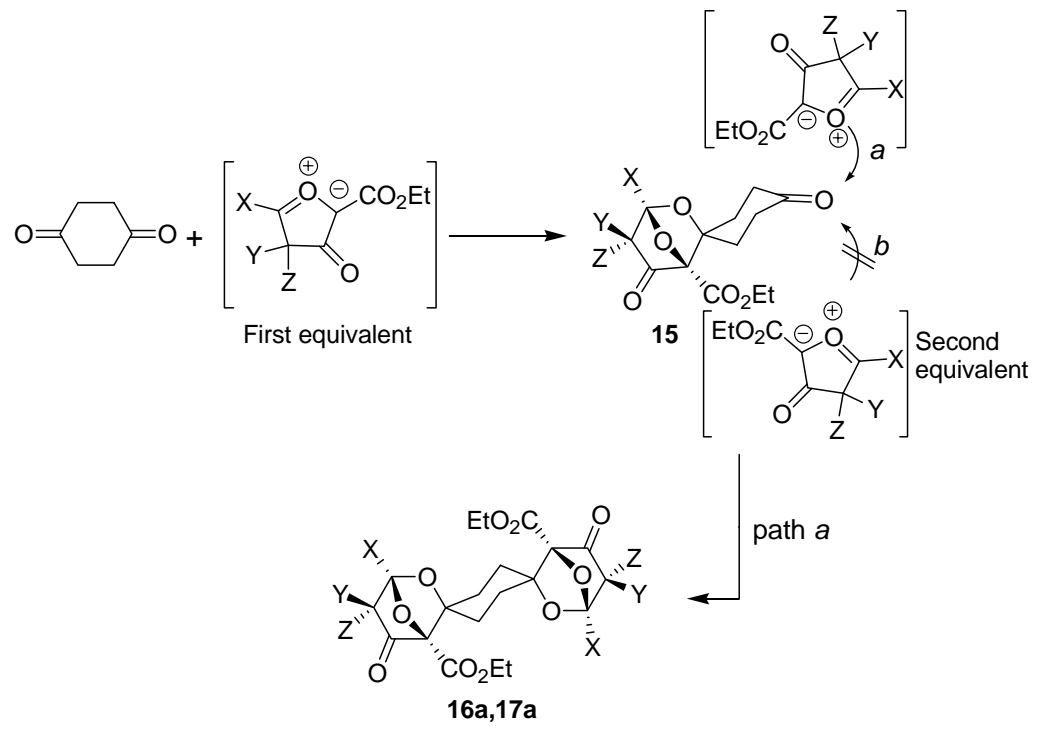

\section{Scheme 4}

Table 4. Reaction of carbonyl ylides $3 \mathbf{b}$ or $\mathbf{6 b}$ with 1,4-cyclohexanedione

\begin{tabular}{llllll}
\hline Entry & $\mathrm{X}$ & $\mathrm{Y}$ & $\mathrm{Z}$ & Product & Yield $(\%)^{\mathrm{a}}$ \\
\hline 1 & $-\left(\mathrm{CH}_{2}\right)_{4^{-}}$ & & $\mathrm{CH}_{3}$ & $\mathbf{1 6 a}$ & 75 \\
2 & $\mathrm{CH}_{3}$ & $\mathrm{CH}_{3}$ & $\mathrm{CH}_{3}$ & $\mathbf{1 7 a}$ & 78 \\
\hline
\end{tabular}

${ }^{\text {a }}$ Yields (unoptimized) refer to isolated and chromatographically pure compounds. 
The formation of the alternative cis-isomers of type 16b and 17b (Figure 4) have been ruled out in the above reactions (Scheme 4) because of the prevailing steric hindrance when the ester substituent present in compound $\mathbf{1 5}$ completely restricts the axial approach of carbonyl ylide dipole. Thus, multiple tandem reactions of diazo ketones $\mathbf{1 b}$ and $\mathbf{4 b}$ having the ester substituent afforded the bis-cycloadducts 16a and 17a in good yield via equatorial addition of carbonyl ylide dipole with high stereoselectivity and chemospecificity. Essentially, in all the above reactions, there was no formation of such 2:1 or 3:1 cycloadducts such as compound 18 (Figure 4) even in the presence of an excess amount of diazo ketone.

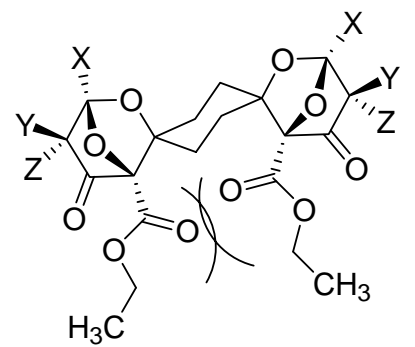

$\mathbf{1 6 b}, \mathbf{1 7 b}$, Presence of steric interaction

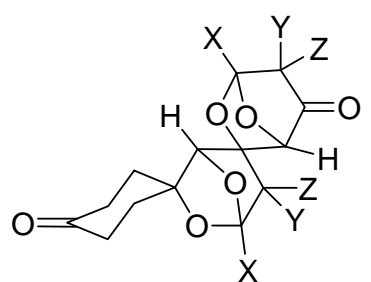

18, Possible 2:1 cycloadduct

\section{Figure 4}

In conclusion, tandem reactions of diazo ketones were demonstrated on examples having 1,2and 1,4-diketo-functionalities placed on rigid as well as flexible frameworks. The transient fivemembered-ring carbonyl ylides generated from $\alpha$-diazo ketones underwent 1,3-dipolar cycloaddition reactions with keto-functionality to afford various bisdioxabicyclo[2.2.1] heptanone ring systems in a chemospecific and diastereoselective manner. In this process, construction of many stereocenters and up to 6 chemical bonds is attained in a single synthetic operation.

\section{Experimental Section}

General Procedures. The melting points are uncorrected. The FT-IR spectra were recorded using $\mathrm{KBr}$ method unless otherwise stated. ${ }^{1} \mathrm{H}$ NMR and ${ }^{13} \mathrm{C}$ NMR spectra were $(200 \mathrm{MHz}$ and $50.3 \mathrm{MHz}$, respectively) referenced to TMS. Carbon types were determined from DEPT ${ }^{13} \mathrm{C}$ NMR experiments. Mass analyses were performed with an ionizing voltage of $70 \mathrm{eV}$ or $\mathrm{FD}^{+}$ method unless otherwise stated. All reactions were carried out under an argon atmosphere and glasswares were dried in an oven before using for catalytic diazo decomposition reaction. Care has been taken to avoid light during the course of catalytic decomposition of $\alpha$-diazo ketones. Dry benzene or dichloromethane has been used as solvent for $\alpha$-diazo ketone decomposition reaction. Analytical thin layer chromatography (TLC) was performed on alumina plates and components were visualized by observation under iodine and UV-Light. Column 
chromatography was performed on a silica gel (100-200 mesh) column unless otherwise stated. Benzene was dried over sodium.

Typical procedure. Method A. To an oven-dried flask, a solution containing the appropriate carbonyl compound $(1 \mathrm{mmol})$ and $0.5 \mathrm{~mol} \%$ of rhodium(II) acetate dimer in $15 \mathrm{~mL}$ of dry dichloromethane (dried over phosphorous pentoxide) was degassed using argon. To this reaction mixture, a solution of appropriate $\alpha$-diazo ketone $1\left(R^{1}=H\right)$ or $4\left(R^{4}=H\right)(3 \mathrm{mmol})$ in dry dichloromethane was added very slowly over a period of $1 \mathrm{~h}$. The progress of the reaction was monitored by TLC. The solvent was removed under reduced pressure and the resulting residue purified using silica gel column chromatography (hexane/EtOAc) unless otherwise stated to afford the respective bis-cycloadducts.

Method B. Reactions utilizing $\alpha$-diazo ketones $\mathbf{1 b}$ and $\mathbf{4 b}$ were performed in dry benzene (dried over sodium) at reflux. The procedure was further followed as described above. All new compounds exhibited spectral data consistent with their structures.

Compound 7. A mixture of anthraquinone $(200 \mathrm{mg}, 1.0 \mathrm{mmol})$ and $\alpha$-diazo ketone 1a $(520 \mathrm{mg}$, $3 \mathrm{mmol})$ was allowed to react in the presence of $5.0 \mathrm{mg}(1.0 \mathrm{~mol} \%)$ of $\mathrm{Rh}_{2}(\mathrm{OAc})_{4}$ in dry $\mathrm{DCM}$ $(20 \mathrm{~mL})$ for $4 \mathrm{~h}$ to afford 7 based on method A. Yield: $341 \mathrm{mg}(60 \%)$; Orange color solid. $\mathrm{mp}$ 214-216 ${ }^{\circ} \mathrm{C}$ (chloroform/hexane). IR (KBr): 2937, 1765, 1456, 1375, 1310, 1044, 996, $764 \mathrm{~cm}^{-1}$. ${ }^{1} \mathrm{H}$ NMR $\left(200 \mathrm{MHz}, \mathrm{CDCl}_{3}\right): \delta 7.72(\mathrm{~d}, J=6.7 \mathrm{~Hz}, 2 \mathrm{H}$, arom- $H), 7.61(\mathrm{~d}, J=7.5 \mathrm{~Hz}, 2 \mathrm{H}$, arom$H), 7.32-7.26(\mathrm{~m}, 4 \mathrm{H}$, arom- $H), 4.72(\mathrm{~s}, 2 \mathrm{H}, \mathrm{OCH}), 2.54-2.45(\mathrm{~m}, 2 \mathrm{H}), 2.18-1.55(\mathrm{~m}, 14 \mathrm{H}), 1.48$ $\left(\mathrm{s}, 6 \mathrm{H}, \mathrm{CH}_{3}\right) .{ }^{13} \mathrm{C} \mathrm{NMR}\left(50.3 \mathrm{MHz}, \mathrm{CDCl}_{3}\right): \delta 211.2(\mathrm{C}=\mathrm{O}), 140.4$ (quat-C), 133.4 (quat-C), $128.1(=\mathrm{CH}), 127.8(=\mathrm{CH}), 126.7(=\mathrm{CH}), 126.1(=\mathrm{CH}), 114.6$ (quat-C), $88.5(\mathrm{OCH}), 84.5$ (quatC), 54.8 (quat-C), $33.5\left(\mathrm{CH}_{2}\right), 26.7\left(\mathrm{CH}_{2}\right), 23.5\left(\mathrm{CH}_{2}\right), 20.3\left(\mathrm{CH}_{2}\right), 15.1\left(\mathrm{CH}_{3}\right)$. MS (EI, $\left.70 \mathrm{eV}\right)$, m/z $512\left(\mathrm{M}^{+}, 0.3\right), 361$ (3), 304 (0.6), 152 (28), 123 (100), 95 (22), 28 (8\%). Anal. Calcd for $\mathrm{C}_{32} \mathrm{H}_{32} \mathrm{O}_{6}$ : requires $\mathrm{C}, 74.98 ; \mathrm{H}, 6.29 \%$. Found: $\mathrm{C}, 75.15 ; \mathrm{H}, 6.32 \%$.

Compound 8. A mixture of anthraquinone $(200 \mathrm{mg}, 1.0 \mathrm{mmol})$ and $\alpha$-diazo ketone $4 \mathrm{a}$ (440 $\mathrm{mg}$, $3 \mathrm{mmol})$ was allowed to react in the presence of $5.0 \mathrm{mg}(1.0 \mathrm{~mol} \%)$ of $\mathrm{Rh}_{2}(\mathrm{OAc})_{4}$ in dry $\mathrm{DCM}$ $(20 \mathrm{~mL})$ for $4 \mathrm{~h}$ to afford 8 based on method A. Yield: $361 \mathrm{mg}(70 \%)$; Orange color solid. $\mathrm{mp}$ 202-204 ${ }^{\circ} \mathrm{C}$ (chloroform/hexane). IR (KBr): 2972, 1767, 1457, 1398, 1304, 1126, 1009, 987, $850,764 \mathrm{~cm}^{-1} .{ }^{1} \mathrm{H}$ NMR $\left(200 \mathrm{MHz}, \mathrm{CDCl}_{3}\right): \delta 7.70(\mathrm{~d}, J=7.1 \mathrm{~Hz}, 2 \mathrm{H}$, arom- $H), 7.62(\mathrm{~d}, J=7.1$ $\mathrm{Hz}, 2 \mathrm{H}$, arom- $H), 7.37-7.22(\mathrm{~m}, 4 \mathrm{H}$, arom- $H), 4.65(\mathrm{~s}, 2 \mathrm{H}, \mathrm{OCH}), 1.92\left(\mathrm{~s}, 6 \mathrm{H}, \mathrm{CH}_{3}\right), 1.44(\mathrm{~s}, 6 \mathrm{H}$, $\left.\mathrm{CH}_{3}\right), 1.16\left(\mathrm{~s}, 6 \mathrm{H}, \mathrm{CH}_{3}\right) .{ }^{13} \mathrm{C} \mathrm{NMR}\left(50.3 \mathrm{MHz}, \mathrm{CDCl}_{3}\right): \delta 211.7$ ( $\left.\mathrm{C}=\mathrm{O}\right), 140.4$ (quat-C), 133.5 (quat-C), $128.2(=\mathrm{CH}), 127.9(=\mathrm{CH}), 126.9(=\mathrm{CH}), 126.1(=\mathrm{CH}), 115.4$ (quat-C), $88.5(\mathrm{OCH})$, 84.4 (quat-C), 55.5 (quat-C), $23.5\left(\mathrm{CH}_{3}\right), 17.6\left(\mathrm{CH}_{3}\right), 15.0\left(\mathrm{CH}_{3}\right)$. MS (FAB), $m / z 483.2\left(\mathrm{M}^{+}\right.$, $\mathrm{Na}$ (5), 335 (13), 259 (10), 239 (12), 127 (100), 57 (90\%). Anal. Calcd for $\mathrm{C}_{28} \mathrm{H}_{28} \mathrm{O}_{6}$ : requires C, 73.03; H, 6.13\%. Found: C, 73.13; H, 6.18\%.

Compounds 10a-c. A mixture of acenaphthenequinone $(250 \mathrm{mg}, 1.3 \mathrm{mmol})$ and $\alpha$-diazo ketone $1 \mathrm{a}(1.0 \mathrm{~g}, 6 \mathrm{mmol})$ was allowed to react in the presence of $5.0 \mathrm{mg}(1.0 \mathrm{~mol} \%) \mathrm{of}_{2} \mathrm{Rh}_{2}(\mathrm{OAc})_{4}$ in dry dichloromethane $(20 \mathrm{~mL})$ for $3 \mathrm{~h}$ to afford bis-cycloadduct 10a along with monocycloadducts $10 \mathrm{~b}$ and $10 \mathrm{c}$ in the ratio of $1: 1: 1.5$ based on method $A$, the pure adducts were 
isolated using alumina column chromatography (hexane/EtOAc). Compound 10a: Yield $133.0 \mathrm{mg}$ (20\%); Colorless solid; mp. 207-209 ${ }^{\circ} \mathrm{C}$ (chloroform/hexane); IR (KBr) 2936, 1765, 1463, 1443, 1376, 1100, 1025, 983, 872, $778 \mathrm{~cm}^{-1} ;{ }^{1} \mathrm{H}$ NMR $\left(200 \mathrm{MHz}, \mathrm{CDCl}_{3}\right) \delta 7.81(\mathrm{~d}, J=$ $8.3 \mathrm{~Hz}, 2 \mathrm{H}$, arom- $H), 7.60(\mathrm{t}, J=7.3 \mathrm{~Hz}, 2 \mathrm{H}$, arom- $H), 7.26(\mathrm{~d}, J=7.1 \mathrm{~Hz}, 2 \mathrm{H}$, arom- $H), 4.76(\mathrm{~s}$, $2 \mathrm{H}, \mathrm{OCH}), 2.61-2.56(\mathrm{~m}, 2 \mathrm{H}), 1.96-1.58(\mathrm{~m}, 14 \mathrm{H}), 1.56\left(\mathrm{~s}, 6 \mathrm{H}, \mathrm{CH}_{3}\right) ;{ }^{13} \mathrm{C} \mathrm{NMR}(50.3 \mathrm{MHz}$, $\left.\mathrm{CDCl}_{3}\right) \delta 211.8(C=\mathrm{O}), 134.8$ (quat-C), 130.4 (quat-C), 128.1 (quat-C), $127.6(=\mathrm{CH}), 125.8$ $(=\mathrm{CH}), 122.0(=\mathrm{CH}), 113.3$ (quat-C), 91.9 (quat-C), $84.7(\mathrm{OCH}), 54.2($ quat $-\mathrm{C}), 31.9\left(\mathrm{CH}_{2}\right), 25.7$ $\left(\mathrm{CH}_{2}\right), 22.9\left(\mathrm{CH}_{2}\right), 19.9\left(\mathrm{CH}_{2}\right), 14.6\left(\mathrm{CH}_{3}\right) . \mathrm{MS}\left(\mathrm{FD}^{+}\right): m / z=486\left[\mathrm{M}^{+}\right]$. Anal. Calcd for $\mathrm{C}_{30} \mathrm{H}_{30} \mathrm{O}_{6}$ : requires $\mathrm{C}, 74.06 ; \mathrm{H}, 6.21 \%$. Found: $\mathrm{C}, 73.80 ; \mathrm{H}, 6.18 \%$. Compound 10b: Yield: 206 mg (31\%); Colorless solid; mp 223-225 ${ }^{\circ} \mathrm{C}$ (chloroform/hexane); IR (KBr) 2939, 1771, 1728, 1604, 14331, 1374, 1269, 1044, 1002, 984, $779 \mathrm{~cm}^{-1} .{ }^{1} \mathrm{H}$ NMR $\left(200 \mathrm{MHz}, \mathrm{CDCl}_{3}\right) \delta 8.15(\mathrm{~d}, J=$ $8.1 \mathrm{~Hz}, 1 \mathrm{H}$, arom- $H), 7.94(\mathrm{~d}, J=7.0 \mathrm{~Hz}, 2 \mathrm{H}$, arom- $H), 7.80(\mathrm{~d}, J=7.0 \mathrm{~Hz}, 1 \mathrm{H}$, arom- $H)$, 7.74$7.64(\mathrm{~m}, 2 \mathrm{H}$, arom- $H), 4.58(\mathrm{~s}, 1 \mathrm{H}, \mathrm{OCH}), 2.27-2.14(\mathrm{~m}, 1 \mathrm{H}), 2.07-1.66(\mathrm{~m}, 7 \mathrm{H}), 1.54(\mathrm{~s}, 3 \mathrm{H}$, $\left.\mathrm{CH}_{3}\right) ;{ }^{13} \mathrm{C} \mathrm{NMR}\left(75.4 \mathrm{MHz}, \mathrm{CDCl}_{3}\right) \delta 210.1(\mathrm{C}=\mathrm{O}), 199.3(\mathrm{C}=\mathrm{O}), 141.4$ (quat-C), 137.9 (quatC), $132.6(=C \mathrm{H}), 131.4$ (quat-C), 130.7 (quat-C), $129.4(=C \mathrm{H}), 128.7(=C \mathrm{H}), 126.4(=C \mathrm{H})$, $122.5(=C H), 121.7(=C H), 115.3$ (quat-C), $87.6(\mathrm{OCH}), 85.9$ (quat-C), 53.9 (quat-C), 32.7 $\left(\mathrm{CH}_{2}\right), 27.3\left(\mathrm{CH}_{2}\right), 23.7\left(\mathrm{CH}_{2}\right), 20.4\left(\mathrm{CH}_{2}\right), 15.4\left(\mathrm{CH}_{3}\right) . \mathrm{MS}\left(\mathrm{FD}^{+}\right): m / z=334\left[\mathrm{M}^{+}\right]$. Anal. Calcd for $\mathrm{C}_{21} \mathrm{H}_{18} \mathrm{O}_{4}$ : requires $\mathrm{C}, 75.43 ; \mathrm{H}, 5.43 \%$. Found: $\mathrm{C}, 75.65 ; \mathrm{H}, 5.50 \%$. Compound 10c: Yield: $127 \mathrm{mg}$ (19\%); Colorless solid; mp 186-188 ${ }^{\circ} \mathrm{C}$ (chloroform/hexane); IR (KBr) 2949, 1762, 1722, 1600, 1436, 1374, 1267, 1048, 1006, 913, $788 \mathrm{~cm}^{-1} .{ }^{1} \mathrm{H}$ NMR (200 MHz, $\left.\mathrm{CDCl}_{3}\right) \delta 8.13$ $(\mathrm{d}, J=8.1 \mathrm{~Hz}, 1 \mathrm{H}$, arom- $H), 8.01-7.90(\mathrm{~m}, 2 \mathrm{H}$, arom- $H), 7.79-7.40(\mathrm{~m}, 2 \mathrm{H}$, arom- $H), 7.38(\mathrm{~d}, J=$ $6.7 \mathrm{~Hz}, 1 \mathrm{H}$, arom-H), $4.73(\mathrm{~s}, 1 \mathrm{H}, \mathrm{OCH}), 2.45-2.39(\mathrm{~m}, 1 \mathrm{H}), 2.04-1.56(\mathrm{~m}, 7 \mathrm{H}), 1.51(\mathrm{~s}, 3 \mathrm{H}$, $\left.\mathrm{CH}_{3}\right) ;{ }^{13} \mathrm{C} \mathrm{NMR}\left(75.4 \mathrm{MHz}, \mathrm{CDCl}_{3}\right) \delta 210.2(\mathrm{C}=\mathrm{O}), 199.4(\mathrm{C}=\mathrm{O}), 142.3$ (quat-C), $132.4(=\mathrm{CH})$, 132.2 (quat-C), 130.8 (quat-C), 129.7 (quat-C), $128.8(=C H), 128.7(=C H), 126.8(=C H), 123.0$ $(=C H), 122.9(=C H), 115.1$ (quat- $C), 87.2(\mathrm{OCH}), 86.0$ (quat-C), 55.0 (quat-C), $32.1\left(C_{2}\right), 26.7$ $\left(\mathrm{CH}_{2}\right), 23.4\left(\mathrm{CH}_{2}\right), 20.3\left(\mathrm{CH}_{2}\right), 15.2\left(\mathrm{CH}_{3}\right) . \mathrm{MS}\left(\mathrm{FD}^{+}\right): m / z=334\left[\mathrm{M}^{+}\right]$. Anal. Calcd for $\mathrm{C}_{21} \mathrm{H}_{18} \mathrm{O}_{4}$ : requires $\mathrm{C}$, 75.43; $\mathrm{H}, 5.43 \%$. Found: $\mathrm{C}, 75.80 ; \mathrm{H}, 5.34 \%$.

Compounds 11a-c. A mixture of acenaphthenequinone $(250 \mathrm{mg}, 1.3 \mathrm{mmol})$ and $\alpha$-diazo ketone 4a $(0.8 \mathrm{~g}, 5 \mathrm{mmol})$ was allowed to react in the presence of $5.0 \mathrm{mg}(1.0 \mathrm{~mol} \%)$ of $\mathrm{Rh}_{2}(\mathrm{OAc})_{4}$ in dry dichloromethane $(20 \mathrm{~mL})$ for $3 \mathrm{~h}$ based on method A to afford bis-cycloadduct 11a along with mono-cycloadducts $\mathbf{1 1 b}$ and 11c in the ratio of $1: 1: 1.5$. The pure adducts were isolated using alumina column chromatography (hexane/EtOAc). Compound 11a: Yield $150.0 \mathrm{mg}$ (25\%); Colorless solid; mp. 218-220 ${ }^{\circ} \mathrm{C}$ (chloroform/hexane); IR (KBr) 2971, 1767, 1466, 1394, 1269 , 1129, 1041, 1005, 984, 854, $779 \mathrm{~cm}^{-1}$; ${ }^{1} \mathrm{H}$ NMR $\left(200 \mathrm{MHz}, \mathrm{CDCl}_{3}\right) \delta 7.75(\mathrm{~d}, J=8.2 \mathrm{~Hz}, 2 \mathrm{H}$, arom- $H$ ), 7.49 (t, $J=7.9 \mathrm{~Hz}, 2 \mathrm{H}$, arom- $H), 7.15(\mathrm{~d}, J=7.1 \mathrm{~Hz}, 2 \mathrm{H}$, arom- $H), 4.67$ (s, 2H, OCH), $1.78\left(\mathrm{~s}, 6 \mathrm{H}, \mathrm{CH}_{3}\right), 1.49\left(\mathrm{~s}, 6 \mathrm{H}, \mathrm{CH}_{3}\right), 1.22\left(\mathrm{~s}, 6 \mathrm{H}, \mathrm{CH}_{3}\right) ;{ }^{13} \mathrm{C} \mathrm{NMR}\left(50.3 \mathrm{MHz}, \mathrm{CDCl}_{3}\right) \delta 212.9$ $(C=\mathrm{O}), 136.7$ (quat-C), 135.4 (quat-C), 131.0 (quat-C), $128.2(=\mathrm{CH}), 126.4(=\mathrm{CH}), 122.6$ $(=\mathrm{CH}), 115.0$ (quat-C), 92.4 (quat-C), $85.3(\mathrm{OCH}), 55.5$ (quat-C), $22.9\left(\mathrm{CH}_{3}\right), 18.7\left(\mathrm{CH}_{3}\right), 14.4$ $\left(\mathrm{CH}_{3}\right)$. MS (EI, $\left.70 \mathrm{eV}\right), \mathrm{m} / z 434\left(\mathrm{M}^{+}, 3.0\right), 414$ (2), 395 (5), 368 (56), 322 (18), 238 (80), 220 (50), 165 (100), 97 (24\%). Anal. Calcd for $\mathrm{C}_{26} \mathrm{H}_{26} \mathrm{O}_{6}$ : requires $\mathrm{C}, 71.87$; H, 6.03\%. Found: C, 
72.07; H, 6.09\%. Compound 11b: Yield: $214 \mathrm{mg}$ (36\%); Colourless solid, m.p. 215-217 ${ }^{\circ} \mathrm{C}$ (Chloroform/hexane, Lit $^{8}$ m.p. 215-217 ${ }^{\circ} \mathrm{C}$ ); IR (KBr) 1762, 1735, 1398, 1269, 1133, $991 \mathrm{~cm}^{-1}$; $\delta_{\mathrm{H}}\left(200 \mathrm{MHz}, \mathrm{CDCl}_{3}\right) 8.03(1 \mathrm{H}, \mathrm{d}, J=8.1 \mathrm{~Hz}$, arom- $H), 7.92(1 \mathrm{H}, \mathrm{d}, J=7.0 \mathrm{~Hz}$, arom- $H), 7.83$ $(1 \mathrm{H}, \mathrm{d}, J=8.1 \mathrm{~Hz}$, arom- $H), 7.70-7.52(2 \mathrm{H}, \mathrm{m}$, arom- $H), 7.28(1 \mathrm{H}, \mathrm{d}, J=7.0 \mathrm{~Hz}$, arom- $H), 4.67$ $(1 \mathrm{H}, \mathrm{s}, \mathrm{OCH}), 1.79\left(3 \mathrm{H}, \mathrm{s}, \mathrm{CH}_{3}\right), 1.44(3 \mathrm{H}, \mathrm{s}, \mathrm{CH}), 1.23\left(3 \mathrm{H}, \mathrm{s}, \mathrm{CH}_{3}\right) ; \delta_{\mathrm{C}}\left(50.3 \mathrm{MHz}, \mathrm{CDCl}_{3}\right)$ $210.8(C=\mathrm{O}), 199.5(C=\mathrm{O}), 142.4$ (quat-C), $132.6(=C \mathrm{H}), 132.3$ (quat-C), 131.0 (quat-C), 129.9 (quat-C), $129.0(=\mathrm{CH}), 128.9(=\mathrm{CH}), 127.0(=\mathrm{CH}), 123.1(=\mathrm{CH}), 123.0(=\mathrm{CH}), 116.2$ (quat-C), $86.0(\mathrm{OCH}), 83.7$ (quat-C), 55.9 (quat-C), $22.5\left(\mathrm{CH}_{3}\right), 18.7\left(\mathrm{CH}_{3}\right), 15.2\left(\mathrm{CH}_{3}\right)$. Compound 11c: Yield: $143 \mathrm{mg}$ (24\%); Colourless solid, m.p. 133-135 ${ }^{\circ} \mathrm{C}$ (chloroform/hexane, Lit ${ }^{8}$ m.p. 133$\left.135^{\circ} \mathrm{C}\right)$; IR (KBr) 1769, 1731, 1435, 1272, 1134, $989 \mathrm{~cm}^{-1} ; \delta_{\mathrm{H}}\left(200 \mathrm{MHz}, \mathrm{CDCl}_{3}\right) 8.17(1 \mathrm{H}, \mathrm{d}, J$ $=8.0 \mathrm{~Hz}$, arom- $H), 7.96(1 \mathrm{H}, \mathrm{d}, J=8.0 \mathrm{~Hz}$, arom- $H), 7.86-7.68(4 \mathrm{H}, \mathrm{m}$, arom- $H), 4.58(1 \mathrm{H}, \mathrm{s}$, $\mathrm{OCH}), 1.82\left(3 \mathrm{H}, \mathrm{s}, \mathrm{CH}_{3}\right), 1.57\left(3 \mathrm{H}, \mathrm{s}, \mathrm{CH}_{3}\right), 1.30\left(3 \mathrm{H}, \mathrm{s}, \mathrm{CH}_{3}\right) ; \delta_{\mathrm{C}}\left(50.3 \mathrm{MHz}, \mathrm{CDCl}_{3}\right) 210.5$ $(C=\mathrm{O}), 199.4(C=\mathrm{O}), 141.6$ (quat-C), 138.2 (quat-C), $132.9(=C \mathrm{H}), 131.6$ (quat-C), 131.0 (quatC), $129.7(=\mathrm{CH}), 128.9(=\mathrm{CH}), 126.7(=\mathrm{CH}), 122.7(=\mathrm{CH}), 122.0(=\mathrm{CH}), 116.5$ (quat-C), 87.5 $(\mathrm{OCH}), 86.1$ (quat-C), 54.7 (quat-C), $22.7\left(\mathrm{CH}_{3}\right), 18.8\left(\mathrm{CH}_{3}\right), 15.7\left(\mathrm{CH}_{3}\right)$.

Compounds 13a and 13b. A mixture of cyclohexa-1,4-dione (200 mg, $1.8 \mathrm{mmol})$ and $\alpha$-diazo ketone 1a $(1.3 \mathrm{~g}, 7 \mathrm{mmol})$ was allowed to react in the presence of $5.0 \mathrm{mg}(1.0 \mathrm{~mol} \%)$ of $\mathrm{Rh}_{2}(\mathrm{OAc})_{4}$ in dry dichloromethane $(20 \mathrm{~mL})$ for $3 \mathrm{~h}$ and the procedure followed by method $\mathrm{A}$ to afford compounds 13a and 13b as a mixture of diastereomers in the ratio of 1:3. The pure diastereomers were separated using alumina column chromatography (hexane/EtOAc). Compound 13a: Yield: $334 \mathrm{mg}$ (45\%); Colorless solid; mp 226-228 ${ }^{\circ} \mathrm{C}$ (chloroform/hexane); IR (KBr) 2932, 1763, 1450, 1376, 1286, 1104, 1028, 957, $867 \mathrm{~cm}^{-1} ;{ }^{1} \mathrm{H}$ NMR $\left(200 \mathrm{MHz}, \mathrm{CDCl}_{3}\right) \delta$ $4.23(\mathrm{~s}, 1 \mathrm{H}, \mathrm{OCH}), 4.21(\mathrm{~s}, 1 \mathrm{H}, \mathrm{OCH}), 2.04-1.38(\mathrm{~m}, 24 \mathrm{H}), 1.07\left(\mathrm{~s}, 3 \mathrm{H}, \mathrm{CH}_{3}\right), 1.05\left(\mathrm{~s}, 3 \mathrm{H}, \mathrm{CH}_{3}\right)$; ${ }^{13} \mathrm{C}$ NMR (50.3 MHz, $\left.\mathrm{CDCl}_{3}\right) \delta 214.1(C=\mathrm{O}), 113.0$ (quat-C), $87.2(\mathrm{OCH}), 80.2$ (quat-C), 53.3 (quat-C), $32.2\left(\mathrm{CH}_{2}\right), 31.9\left(\mathrm{CH}_{2}\right), 31.4\left(\mathrm{CH}_{2}\right), 30.3\left(\mathrm{CH}_{2}\right), 29.0\left(\mathrm{CH}_{2}\right), 28.1\left(\mathrm{CH}_{2}\right), 23.6\left(\mathrm{CH}_{2}\right)$, $20.7\left(\mathrm{CH}_{2}\right), 15.3\left(\mathrm{CH}_{3}\right)$. MS (EI) (\%): $\mathrm{m} / z 416\left(\mathrm{M}^{+}, 30\right), 388$ (8), 329 (10), 277 (12), 263 (11), 198 (22), 153 (29), 123 (25), 112 (63), 83 (62), 69 (39), 55 (100). Anal. Calcd for $\mathrm{C}_{24} \mathrm{H}_{32} \mathrm{O}_{6}$ : requires C, 69.21; H, 7.74. Found: C, 69.35; H, 7.69\%. Compound 13b: Yield: $126 \mathrm{mg}$ (17\%); Colorless solid; mp 203-205 ${ }^{\circ} \mathrm{C}$ (chloroform/hexane); IR (KBr) 2940, 1763, 1448, 1374, 1288, 1227, 1102, 1027, 981, $867 \mathrm{~cm}^{-1} ;{ }^{1} \mathrm{H}$ NMR (200 MHz, $\left.\mathrm{CDCl}_{3}\right) \delta 4.28$ (s, 2H, OCH), 1.95-1.41 $(\mathrm{m}, 24 \mathrm{H}), 1.07\left(\mathrm{~s}, 3 \mathrm{H}, \mathrm{CH}_{3}\right), 1.06\left(\mathrm{~s}, 3 \mathrm{H}, \mathrm{CH}_{3}\right) ;{ }^{13} \mathrm{C} \mathrm{NMR}\left(50.3 \mathrm{MHz}, \mathrm{CDCl}_{3}\right) \delta 214.4(C=\mathrm{O})$, $214.1\left(C=\mathrm{O}\right.$ ), 112.8 (quat- $C$ ), 85.7 (quat-C), 80.3 (quat-C), 53.3 (quat-C), $32.5\left(\mathrm{CH}_{2}\right), 32.2$ $\left(\mathrm{CH}_{2}\right), 31.8\left(\mathrm{CH}_{2}\right), 30.3\left(\mathrm{CH}_{2}\right), 29.2\left(\mathrm{CH}_{2}\right), 27.9\left(\mathrm{CH}_{2}\right), 23.5\left(\mathrm{CH}_{2}\right), 20.6\left(\mathrm{CH}_{2}\right), 15.3\left(\mathrm{CH}_{3}\right)$. MS (EI) (\%): m/z $416\left(\mathrm{M}^{+}, 45\right), 388$ (5), 329 (10), 277 (12), 263 (20), 198 (14), 153 (28), 123 (35), 112 (62), 83 (63), 69 (39), 55 (100). Anal. Calcd for $\mathrm{C}_{24} \mathrm{H}_{32} \mathrm{O}_{6}$ : requires C, 69.21; H, 7.74. Found: C, 69.38; H, 7.78\%.

Compounds 14a and 14b. A mixture of cyclohexa-1,4-dione $(200 \mathrm{mg}, 1.8 \mathrm{mmol})$ and $\alpha$-diazo ketone 4a $(1.1 \mathrm{~g}, 7 \mathrm{mmol})$ was allowed to react in the presence of $5.0 \mathrm{mg}(1.0 \mathrm{~mol} \%)$ of $\mathrm{Rh}_{2}(\mathrm{OAc})_{4}$ in dry dichloromethane $(20 \mathrm{~mL})$ for $3 \mathrm{~h}$ and the procedure followed by method $\mathrm{A}$ to afford products 14a and $\mathbf{1 4 b}$ as a diastereomeric mixture in the ratio of 1:2. The pure isomers 
were separated using alumina column chromatography (hexane/EtOAc). Compound 14a: Yield: $150 \mathrm{mg}$ (23\%); Colorless solid; mp 228-230 ${ }^{\circ} \mathrm{C}$ (chloroform/hexane); IR (KBr) 2966, 1766, 1440, 1396, 1269, 1127, 997, $855 \mathrm{~cm}^{-1} ;{ }^{1} \mathrm{H}$ NMR (200 MHz, $\left.\mathrm{CDCl}_{3}\right) \delta 4.18$ (s, 1H, OCH), 4.17 (s, 1H, OCH), 1.78-1.68 (m, 6H), 1.49 (s, 3H, CH $), 1.48$ (s, 3H, CH $), 1.44-1.35$ (m, 2H), 1.06 (s, 6H, $\left.\mathrm{CH}_{3}\right), 1.04\left(\mathrm{~s}, 3 \mathrm{H}, \mathrm{CH}_{3}\right), 1.02\left(\mathrm{~s}, 3 \mathrm{H}, \mathrm{CH}_{3}\right) ;{ }^{13} \mathrm{C} \mathrm{NMR}\left(50.3 \mathrm{MHz}, \mathrm{CDCl}_{3}\right) \delta 214.6(\mathrm{C}=\mathrm{O})$, 114.1 (quat-C), $86.9(\mathrm{OCH}), 80.0$ (quat-C), 54.0 (quat-C), $32.1\left(\mathrm{CH}_{2}\right), 31.2\left(\mathrm{CH}_{2}\right), 28.8\left(\mathrm{CH}_{2}\right)$, $27.8\left(\mathrm{CH}_{2}\right), 21.9\left(\mathrm{CH}_{3}\right), 18.6\left(\mathrm{CH}_{3}\right), 16.1\left(\mathrm{CH}_{3}\right)$. MS (EI) m/z (\%): $364\left(\mathrm{M}^{+}, 22\right), 304(18), 276$ (10), 219 (8), 192 (20), 177 (25), 97 (23), 70 (41), 43 (100). Anal. Calcd for $\mathrm{C}_{20} \mathrm{H}_{28} \mathrm{O}_{6}$ : requires C, 65.91; H, 7.74. Found: C, 66.08; H, 7.79\%. Compound 14b: Yield: $292 \mathrm{mg}$ (45\%); Colorless solid; mp 181-183 ${ }^{\circ} \mathrm{C}$ (chloroform/hexane); IR (KBr) 2971, 1764, 1444, 1395, 1268, 1134, 994, $855 \mathrm{~cm}^{-1} ;{ }^{1} \mathrm{H}$ NMR $\left(200 \mathrm{MHz}, \mathrm{CDCl}_{3}\right) \delta 4.25(\mathrm{~s}, 1 \mathrm{H}, \mathrm{OCH}), 4.24(\mathrm{~s}, 1 \mathrm{H}, \mathrm{OCH}), 1.92-1.53(\mathrm{~m}$, $8 \mathrm{H}), 1.49\left(\mathrm{~s}, 3 \mathrm{H}, \mathrm{CH}_{3}\right), 1.48\left(\mathrm{~s}, 3 \mathrm{H}, \mathrm{CH}_{3}\right), 1.06\left(\mathrm{~s}, 6 \mathrm{H}, \mathrm{CH}_{3}\right), 1.03\left(\mathrm{~s}, 6 \mathrm{H}, \mathrm{CH}_{3}\right)$; ${ }^{13} \mathrm{C} \mathrm{NMR}$ $\left(50.3 \mathrm{MHz}, \mathrm{CDCl}_{3}\right) \delta 214.8(C=\mathrm{O}), 214.6(C=\mathrm{O}), 113.9$ (quat-C), $85.5(\mathrm{OCH}), 80.2$ (quat-C), 54.0 (quat-C), $32.5\left(\mathrm{CH}_{2}\right), 32.2\left(\mathrm{CH}_{2}\right), 29.6\left(\mathrm{CH}_{2}\right), 29.1\left(\mathrm{CH}_{2}\right), 21.9\left(\mathrm{CH}_{3}\right), 18.5\left(\mathrm{CH}_{3}\right), 16.0$ $\left(\mathrm{CH}_{3}\right)$; MS (EI) m/z (\%): $364\left(\mathrm{M}^{+}, 7\right), 304$ (52), 276 (33), 261 (11), 216 (14), 192 (54), 191 (43), 188 (21), 177 (100), 174 (60), 122 (45), 93 (15), 70 (70), 57 (13); Anal. Calcd for $\mathrm{C}_{20} \mathrm{H}_{28} \mathrm{O}_{6}$ : requires $\mathrm{C}, 65.91 ; \mathrm{H}, 7.74$. Found: $\mathrm{C}, 66.15 ; \mathrm{H}, 7.72 \%$.

Compound 16a. A mixture of cyclohexa-1,4-dione (150 mg, $1.3 \mathrm{mmol}$ ) and $\alpha$-diazo ketone $\mathbf{1 b}$ ( $1 \mathrm{~g}, 3 \mathrm{mmol})$ was allowed to react in the presence of $5.0 \mathrm{mg}(1.0 \mathrm{~mol} \%)$ of $\mathrm{Rh}_{2}(\mathrm{OAc})_{4}$ in dry benzene $(20 \mathrm{~mL})$ for $8 \mathrm{~h}$ reflux based on method B to afford compound 16a. Yield: $563 \mathrm{mg}$ Yield: (75\%); Colorless solid. mp 146-148 ${ }^{\circ} \mathrm{C}$ (chloroform/hexane). IR(KBr): 2941, 1778, 1751, 1449, 1380, 1322, 1303, 1174, 1133, 1082, 1048, $982760 \mathrm{~cm}^{-1} .{ }^{1} \mathrm{H}$ NMR $\left(200 \mathrm{MHz}, \mathrm{CDCl}_{3}\right): \delta$ 4.44-4.25 (m, 4H, OCH $\mathrm{OH}_{2}, 2.04-1.94(\mathrm{~m}, 4 \mathrm{H}), 1.73-1.48(\mathrm{~m}, 20 \mathrm{H}), 1.37\left(\mathrm{t}, J=7.0 \mathrm{~Hz}, 6 \mathrm{H}, \mathrm{CH}_{3}\right)$, $1.12\left(\mathrm{~s}, 6 \mathrm{H}, \mathrm{CH}_{3}\right) .{ }^{13} \mathrm{C} \mathrm{NMR}\left(50.3 \mathrm{MHz}, \mathrm{CDCl}_{3}\right): \delta 207.7(\mathrm{C}=\mathrm{O}), 207.5(\mathrm{C}=\mathrm{O}), 163.7(\mathrm{COO})$, 110.8 (quat-C), 110.0 (quat-C), 93.4 (quat-C), 92.8 (quat-C), 82.0 (quat-C), 81.8 (quat-C), 62.7 $\left(\mathrm{OCH}_{2}\right), 62.5\left(\mathrm{OCH}_{2}\right), 53.5$ (quat-C), $32.0\left(\mathrm{CH}_{2}\right), 30.0\left(\mathrm{CH}_{2}\right), 29.7\left(\mathrm{CH}_{2}\right), 28.9\left(\mathrm{CH}_{2}\right), 28.7$ $\left(\mathrm{CH}_{2}\right), 27.9\left(\mathrm{CH}_{2}\right), 27.7\left(\mathrm{CH}_{2}\right), 23.1\left(\mathrm{CH}_{2}\right), 20.4\left(\mathrm{CH}_{2}\right), 15.5\left(\mathrm{CH}_{3}\right), 14.6\left(\mathrm{CH}_{3}\right)$. MS (EI, $\left.70 \mathrm{eV}\right)$, m/z $560\left(\mathrm{M}^{+}, 6\right), 514$ (3), 336 (9), 226 (15), 225 (82), 224 (16), 202 (23), 151 (34), 139 (15), 123 (41), 112 (40), 111 (46), 83 (97), 55 (100\%). Anal. Calcd for $\mathrm{C}_{30} \mathrm{H}_{40} \mathrm{O}_{10}$ : requires C, 64.27; H, 7.19\%. Found: C, 64.10; 7.23\%.

Compound 17a. A mixture of cyclohexa-1,4-dione $(150 \mathrm{mg}, 1.3 \mathrm{mmol})$ and $\alpha$-diazo ketone $4 \mathbf{b}$ (900 mg, $3 \mathrm{mmol})$ was allowed to react in the presence of $5.0 \mathrm{mg}(1.0 \mathrm{~mol} \%)$ of $\mathrm{Rh}_{2}(\mathrm{OAc})_{4}$ in dry benzene $(20 \mathrm{~mL})$ for $8 \mathrm{~h}$ reflux based on method $\mathrm{B}$ to afford compound 17a. Yield: $530 \mathrm{mg}$ Yield: (78\%); Colorless solid. mp 102-104 ${ }^{\circ} \mathrm{C}$ (chloroform/hexane). IR (KBr): 2984, 1780, 1746, 1468, 1399, 1376, 1332, 1268, 1120, 1061, $739 \mathrm{~cm}^{-1} .{ }^{1} \mathrm{H}$ NMR (200 MHz, $\left.\mathrm{CDCl}_{3}\right): \delta 4.44-4.25$ $\left(\mathrm{m}, 4 \mathrm{H}, \mathrm{OCH}_{2}\right), 2.07-2.04(\mathrm{~m}, 2 \mathrm{H}), 1.81-1.66(\mathrm{~m}, 6 \mathrm{H}), 1.51\left(\mathrm{~s}, 6 \mathrm{H}, \mathrm{CH}_{3}\right), 1.37(\mathrm{t}, J=7.7 \mathrm{~Hz}, 6 \mathrm{H}$, $\left.\mathrm{CH}_{3}\right), 1.11\left(\mathrm{~s}, 6 \mathrm{H}, \mathrm{CH}_{3}\right), 1.09\left(\mathrm{~s}, 6 \mathrm{H}, \mathrm{CH}_{3}\right) .{ }^{13} \mathrm{C} \mathrm{NMR}\left(50.3 \mathrm{MHz}, \mathrm{CDCl}_{3}\right): \delta 208.3(\mathrm{C}=\mathrm{O}), 208.0$ $(C=\mathrm{O}), 163.9$ (COO), 163.7 (COO), 112.2 (quat-C), 111.4 (quat-C), 92.7 (quat-C), 82.1 (quatC), $63.0\left(\mathrm{OCH}_{2}\right), 62.9\left(\mathrm{OCH}_{2}\right), 54.4$ (quat-C), $30.1\left(\mathrm{CH}_{2}\right), 29.9\left(\mathrm{CH}_{2}\right), 28.9\left(\mathrm{CH}_{2}\right), 28.7\left(\mathrm{CH}_{2}\right)$, $22.1\left(\mathrm{CH}_{3}\right), 18.8\left(\mathrm{CH}_{3}\right), 16.1\left(\mathrm{CH}_{3}\right), 14.8\left(\mathrm{CH}_{3}\right)$. MS (EI, $\left.70 \mathrm{eV}\right), \mathrm{m} / z 508\left(\mathrm{M}^{+}, 6\right), 448(19), 402$ 
(12), 251 (15), 250 (41), 199 (100), 153 (14), 97 (30), 70 (86), 57 (40\%). Anal. Calcd for $\mathrm{C}_{26} \mathrm{H}_{36} \mathrm{O}_{10}$ : requires $\mathrm{C}, 61.40 ; \mathrm{H}, 7.14 \%$. Found: $\mathrm{C}, 61.51 ; 7.19 \%$.

\section{Supplementary information}

Crystallographic data for 13a,14b,16a have been deposited with the Cambridge Crystallographic Data Centre as supplementary publication no CCDC-253358 - 253360. Copies of the data can be obtained free of charge on application to 12, Union Road, Cambridge CB2 1EZ, UK. (fax: (+44) 1223-336-033; e-mail: deposit@ccdc.cam.ac.uk. Tables of atomic coordinates, bond lengths and bond angles of bis-dioxabicyclo[2.2.1] heptanone derivatives 13a,14b,16a are provided.

\section{Acknowledgements}

This research was supported by the Department of Science and Technology, New Delhi. We are grateful to Dr. M. Nethaji, IISc, Bangalore, for providing single crystal X-ray crystallographic analysis of compound 13a. J. K. thanks CSIR, New Delhi for the award of a Junior Research Fellowship. See Page 232

\section{References and Notes}

1. (a) Ho, T. L. Tandem Organic Reactions, Wiley: New York, 1992. (b) Nicolaou, K. C.; Montagnon, T.; Snyder, S. A. Chem. Commun. 2003, 551. (c) Waldmann, H. Domino Reaction in Organic Synthesis Highlight II, VCH: Weinheim, 1995; p 193. (d) Wender, P. A. Chem. Rev. 1996, 96, pp 1-600. (e) Tietze, L. F.; Beifuss, U. Angew. Chem., Int. Ed. 1993, 32, 131. (f) Curran, D. P. In Comprehensive Organic Synthesis; Trost, B. M., Fleming, I., Eds.; Pergamon: Oxford, 1991; Vol. 4, pp 779-831.

2. Doyle, M. P.; McKervey, M. A.; Ye, T. Modern Catalytic Methods for Organic Synthesis with Diazo Compounds. From Cyclopropanes to Ylides; Wiley-Interscience: New York, 1998.

3. For reviews of metal-carbene transformations see: (a) Mehta, G.; Muthusamy, S. Tetrahedron 2002, 58, 9477. (b) Hodgson, D. M.; Pierard, F. Y. T. M.; Stupple, P. A. Chem. Soc. Rev. 2001, 30, 50. (c) Doyle, M. P.; Forbes, D. C. Chem. Rev. 1998, 98, 911. (d) Padwa, A.; Weingarten, M. D. Chem. Rev. 1996, 96, 223.

4. (a) Padwa, A.; Curtis, E. A.; Sandanayaka, V. P. J. Org. Chem. 1997, 62, 1317. (b) McMorris, T. C.; Hu, Y.; Yu, J.; Kelner, M. J. J. Chem. Soc., Chem. Commun. 1997, 315. (c) Kinder, Jr., F. R.; Bair, K. W. J. Org. Chem. 1994, 59, 6965. (d) McMills, M. C.; Zhuang, L.; 
Wright, D. L.; Watt, W. Tetrahedron Lett. 1994, 35, 8311. (e) Dauben, W. G.; Dinges, J.; Smith, T. C. J. Org. Chem. 1993, 58, 7635.

5. Nair, V.; Sheela, K. C.; Sethumadhavan, D.; Dhanya, R.; Rath, N. P. Tetrahedron 2002, 58, 4171.

6. Muthusamy, S.; Babu, S. A.; Gunanathan, C.; Suresh, E.; Dastidar, P.; Jasra, R. V. Tetrahedron 2000, 56, 6307.

7. Pirrung, M. C.; Kaliappan, K. P. Org. Lett. 2000, 2, 353.

8. Muthusamy, S.; Babu, S. A.; Nethaji, M. Tetrahedron 2003, 59, 8117.

9. (a) Ibata, T.; Toyada, J. Bull. Chem. Soc. Jpn. 1986, 59, 2489. (b) Padwa, A.; Fryxell, G. E.; Zhi, L. J. Am. Chem. Soc. 1990, 112, 3100.

10. Padwa, A.; Chinn, R. L.; Zhi, L. Tetrahedron Lett. 1989, 30, 1491.

11. (a) Hodgson, D. M.; Bailey, J. M.; Villalonga-Barber, C.; Drew, M. G. B.; Harrison, T. J. Chem. Soc., Perkin Trans. 1 2000, 3432. (b) Kataoka, O.; Kitagaki, S.; Watanabe, N.; Kobayashi, J.; Nakumura, S.; Shiro, M.; Hashimoto, S. Tetrahedron Lett. 1998, 39, 2371.

12. Loukaci, A.; Kayser, O.; Bindseil, K.-U.; Siems, K. Frevert, J.; Abreu, P. M. J. Nat. Prod. 2000, 63, 52.

13. Mahmoud, A. A. Phytochemistry 1997, 45, 1633.

14. Tomono, Y.; Hirota, H.; Fusetani, N. J. Org. Chem. 1999, 64, 2272.

15. (a) Muthusamy, S.; Gunanathan, C.; Nethaji, M. J. Org. Chem. 2004, 69, 5631. (b) Muthusamy, S.; Gunanathan, C.; Suresh, E. Tetrahedron 2004, 60, 7885. (c) Muthusamy, S.; Gunanathan, C. J. Chem. Soc., Chem. Commun. 2003, 440. (d) Muthusamy, S.; Babu, S. A.; Gunanathan, C.; Ganguly, B.; Suresh, E.; Dastidar, P. J. Org. Chem. 2002, 67, 8019. (e) Muthusamy, S.; Babu, S. A.; Gunanathan, C.; Suresh, E.; Dastidar, P. Bull. Chem. Soc. Jpn. 2002, 75, 801. (f) Muthusamy, S.; Babu, S. A.; Gunanathan, C. Tetrahedron Lett. 2002, 43, 3931. (g) Muthusamy, S.; Babu, S. A.; Gunanathan, C. Tetrahedron Lett. 2002, 43, 5981.

16. Muthusamy, S.; Krishnamurthi, J.; Nethaji, M. Tetrahedron Lett. 2004, 45, 6485.

17. Muthusamy, S.; Gunanathan, C.; Babu, S. A. Tetrahedron Lett. 2001, 42, 523.

18. Crystal data for compound 13a: Colorless rectangular. $\mathrm{C}_{24} \mathrm{H}_{32} \mathrm{O}_{6}, M=416.50,0.42 \times 0.18 \times$ $0.06 \mathrm{~mm}^{3}$, monoclinic, space group $21 / \mathrm{c}$ with $a=13.546(4) \AA, b=8.249(3) \AA, c=19.564(6)$ $\AA, V=2146.1(12) \AA^{3}, T=293(2) \mathrm{K}, R_{1}=0.0570, w R_{2}=0.1257$ on observed data, $\mathrm{z}=4$, $D_{\text {calcd }}=1.289 \mathrm{~g} \mathrm{~cm}^{-3}, F(000)=896$, Absorption coefficient $=0.092 \mathrm{~mm}^{-1}, \lambda=0.71073 \AA$, 15789 reflections were collected on a smart apex CCD single crystal diffractometer, 4213 observed reflections $(I \geq 2 \sigma(I))$. The largest difference peak and hole $=0.211$ and $-0.151 e \AA^{-3}$, respectively. The structure was solved by direct methods and refined by full-matrix least squares on $F^{2}$ using SHELXL-97 software.

19. Crystal data for compound 14b: Colorless rectangular. $\mathrm{C}_{20} \mathrm{H}_{28} \mathrm{O}_{6}, M=364.42,0.34 \times 0.22 \times$ $0.18 \mathrm{~mm}^{3}$, monoclinic, space group $21 / \mathrm{c}$ with $a=14.2634(10) \AA, b=11.3716(8) \AA, c=$ $11.7879(8) \AA, V=1898.6(2) \AA^{3}, T=273(2) \mathrm{K}, R_{1}=0.0458, w R_{2}=0.1211$ on observed data, $\mathrm{z}=4, D_{\text {calcd }}=1.275 \mathrm{~g} \mathrm{~cm}^{-3}, F(000)=784$, Absorption coefficient $=0.093 \mathrm{~mm}^{-1}, \lambda=0.71073$ $\AA, 11196$ reflections were collected on a smart apex ccd single crystal CCD diffractometer, 
4393 observed reflections $(I \geq 2 \sigma(I))$. The largest difference peak and hole $=0.301$ and $0.191 e \AA^{-3}$, respectively. The structure was solved by direct methods and refined by fullmatrix least squares on $F^{2}$ using SHELXL-97 software.

20. Crystal data for compound 16a: Colorless rectangular. $\mathrm{C}_{30} \mathrm{H}_{40} \mathrm{O}_{10}, M=560.62,0.30 \times 0.10 \times$ $0.06 \mathrm{~mm}^{3}$, monoclinic, space group $21 / \mathrm{c}$ with $a=12.028(2) \AA, b=7.3281(14) \AA, c=$ 16.693(3) $\AA, V=1447.1(5) \AA^{3}, T=293(2) \mathrm{K}, R_{1}=0.0555, w R_{2}=0.1597$ on observed data, $\mathrm{z}$ $=4, D_{\text {calcd }}=1.287 \mathrm{~g} \mathrm{~cm}^{-3}, F(000)=600$, Absorption coefficient $=0.096 \mathrm{~mm}^{-1}, \lambda=0.71073$ $\AA$, 8509 reflections were collected on a smart apex ccd single crystal CCD diffractometer, 3360 observed reflections $(I \geq 2 \sigma(I))$. The largest difference peak and hole $=0.363$ and $0.285 e \AA^{-3}$, respectively. The structure was solved by direct methods and refined by fullmatrix least squares on $F^{2}$ using SHELXL-97 software. 